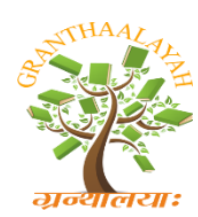

INTERNATIONAL JOURNAL OF RESEARCH GRANTHAALAYAH A knowledge Repository

\title{
Social
}

\section{A STUDY OF AWARENESS ON E-RESOURCES AMONG B.ED STUDENT TEACHERS}

\author{
Nithya.J ${ }^{* 1}$, Ms.Malathi.V.A ${ }^{2}$ \\ ${ }^{* 1}$ MEd Scholar, RVS College of Education, India \\ ${ }^{2}$ Assistant Professor in Education, RVS College of Education, India
}

DOI: https://doi.org/10.29121/granthaalayah.v5.i6.2017.2060

\begin{abstract}
The essential of the study is the multiplying unfamiliarity of e-resources due to the let-down of electricity, which is a common problem in Palakkad area. Related other reasons are absence of time to utilize the I.T lab in time. The investigators and students from all disciplines are set to use e-Books in future. In order to build more teachers professional development and to improve the research practise they need in e-journals and e-books. The study aimed to examine the awareness on e-resources among B.Ed student teachers. The investigator adopted survey method to study the awareness on e-resources among B.Ed student teachers. For this study a sample of 200 B.Ed student teachers from three B.Ed training colleges which are situated in and around Palakkad district in Kerala selected by the investigator using simple random sampling technique. The findings reveal that there is no significant difference in the awareness of e-resources and eresource technology among B.Ed Student Teachers.
\end{abstract}

Keywords: E-Resources; Awareness; Education.

Cite This Article: Nithya.J, and Ms.Malathi.V.A. (2017). "A STUDY OF AWARENESS ON ERESOURCES AMONG B.ED STUDENT TEACHERS." International Journal of Research - Granthaalayah, 5(6), 489-494. https://doi.org/10.29121/granthaalayah.v5.i6.2017.2060.

\section{Introduction}

The educational sector, since the beginning of e-learning, is enduring incredible change on daily basis. E-learning itself is a cut down approach to education and knowledge and there is the need for teachers to take advantage of the abundant benefit and chances it offers. One way to do this is to become computer literate. Secondly, educators should pursue knowledge of the various elearning resources available to them. Most prominently, teachers and learners should make an effort to apply the e- learning resources in core curriculum implementation. Being computer literate, being able to distinguish e-learning resources and being able to put on them in teaching are the key factors in the operative utilization of electronic resources in the present computer age. Palakkad district is roughcast with problems of students' poor performance in public 
examinations and there is the need therefore for teachers to encirclement e-learning as a better substitute to the old-fashioned mode of teaching.

\subsection{Objectives of the Study}

There are two main types of objectives undertaken by the investigator in this study work.

\subsubsection{General Objectives}

1) To study the awareness of e-resources among B.Ed Student teachers in Palakkad District.

2) To adopt questionnaire on awareness of e-resources and e-resources technology among B.Ed Student teachers.

\subsubsection{Specific Objectives}

1) To find out the awareness of e-resources among B.Ed Student teachers.

2) To find out the B.Ed student teachers' awareness \& intentions of some common Eresources technology related actions.

3) To find out the impact of personal variables like Sex, Medium of instruction, Location of the college, Nature of college, Type of family, Parents education, Parents occupation and Parents monthly income on awareness of e-resources of B.Ed Student teachers.

\section{Research Design}

The investigator adopted survey method to study the awareness of e-resources among B.Ed Student teachers. For this study a sample of 200 B.Ed Student teachers from three B.Ed Colleges which are situated in and around Palakkad district in Kerala were selected by the investigator using simple random sampling technique.

Table 1: Distribution of Samples based on Variables

\begin{tabular}{|c|c|c|c|c|c|}
\hline S.NO & Category & Subgroups & Number & $\%$ & Total \\
\hline \multirow[b]{2}{*}{1.} & \multirow[b]{2}{*}{ Age } & Below 25 years & 180 & $90 \%$ & \multirow[b]{2}{*}{200} \\
\hline & & $25-35$ years & 20 & $10 \%$ & \\
\hline \multirow[b]{2}{*}{2.} & \multirow[b]{2}{*}{ Gender } & Male & 7 & $3.5 \%$ & \multirow[b]{2}{*}{200} \\
\hline & & Female & 193 & $96.5 \%$ & \\
\hline \multirow{4}{*}{3.} & \multirow{4}{*}{$\begin{array}{l}\text { Medium of } \\
\text { Instruction }\end{array}$} & Malayalam & 83 & $41.5 \%$ & \multirow{4}{*}{200} \\
\hline & & English & 105 & $52.5 \%$ & \\
\hline & & Hindi & 2 & $1 \%$ & \\
\hline & & Tamil & 10 & $5 \%$ & \\
\hline \multirow[b]{2}{*}{4.} & \multirow{2}{*}{$\begin{array}{l}\text { Location of the } \\
\text { College }\end{array}$} & Urban & 79 & $39.5 \%$ & \multirow[b]{2}{*}{200} \\
\hline & & Rural & 121 & $60.5 \%$ & \\
\hline \multirow[t]{3}{*}{5 . } & \multirow[t]{3}{*}{ Nature of College } & Boys & 1 & $0.5 \%$ & \multirow{3}{*}{200} \\
\hline & & Girls & 116 & $58 \%$ & \\
\hline & & Co-Education & 83 & $41.5 \%$ & \\
\hline 6. & General & UG & 99 & $49.5 \%$ & 200 \\
\hline
\end{tabular}




\begin{tabular}{|c|c|c|c|c|c|}
\hline & Qualification & $\overline{P G}$ & 101 & $50.5 \%$ & \\
\hline \multirow[t]{2}{*}{7.} & \multirow[t]{2}{*}{ Type of Family } & Nuclear Family & 174 & $87 \%$ & \multirow[t]{2}{*}{200} \\
\hline & & Joint Family & 26 & $13 \%$ & \\
\hline \multirow[t]{5}{*}{8.} & \multirow{5}{*}{$\begin{array}{c}\text { Educational } \\
\text { Qualification of } \\
\text { father }\end{array}$} & Below 10 & 147 & $73.5 \%$ & \multirow[t]{5}{*}{200} \\
\hline & & Diploma & 9 & $4.5 \%$ & \\
\hline & & $\mathrm{UG}$ & 34 & $17 \%$ & \\
\hline & & $P G$ & 9 & $4.5 \%$ & \\
\hline & & Professional & 1 & $0.5 \%$ & \\
\hline
\end{tabular}

\begin{tabular}{|c|c|c|c|c|c|}
\hline \multirow[t]{5}{*}{9.} & \multirow{5}{*}{$\begin{array}{c}\text { Educational } \\
\text { Qualification of } \\
\text { mother }\end{array}$} & Below 10 & 151 & $75.5 \%$ & \multirow[t]{5}{*}{200} \\
\hline & & Diploma & 6 & $3 \%$ & \\
\hline & & UG & 30 & $15 \%$ & \\
\hline & & PG & 12 & $6 \%$ & \\
\hline & & Professional & 1 & $0.5 \%$ & \\
\hline \multirow[t]{6}{*}{10.} & \multirow{6}{*}{$\begin{array}{l}\text { Occupation of } \\
\text { Father }\end{array}$} & Daily Wagers & 75 & $37.5 \%$ & \multirow[t]{6}{*}{200} \\
\hline & & Farmer & 28 & $14 \%$ & \\
\hline & & Govt.Job & 13 & $6.5 \%$ & \\
\hline & & Private & 27 & $13.5 \%$ & \\
\hline & & Business & 56 & $28 \%$ & \\
\hline & & Others & 1 & $0.5 \%$ & \\
\hline \multirow[t]{6}{*}{11.} & \multirow{6}{*}{$\begin{array}{l}\text { Occupation of } \\
\text { Mother }\end{array}$} & Daily Wagers & 53 & $26.5 \%$ & \multirow[t]{6}{*}{200} \\
\hline & & Farmer & 9 & $4.5 \%$ & \\
\hline & & Govt.Job & 11 & $5.5 \%$ & \\
\hline & & Private & 30 & $15 \%$ & \\
\hline & & Business & 6 & $3 \%$ & \\
\hline & & Home Maker & 91 & $45.5 \%$ & \\
\hline \multirow[t]{4}{*}{12.} & \multirow{4}{*}{$\begin{array}{l}\text { Monthly income of } \\
\text { Father }\end{array}$} & Below Rs.5000 & 60 & $30 \%$ & \multirow[t]{4}{*}{200} \\
\hline & & Rs.5000-Rs.15000 & 50 & $25 \%$ & \\
\hline & & $\begin{array}{l}\text { Rs.15000- } \\
\text { Rs.20000 }\end{array}$ & 57 & $28.5 \%$ & \\
\hline & & Above Rs.20000 & 33 & $16.5 \%$ & \\
\hline \multirow[t]{4}{*}{13.} & \multirow{4}{*}{$\begin{array}{l}\text { Monthly income of } \\
\text { mother }\end{array}$} & Below Rs.5000 & 126 & $63 \%$ & \multirow[t]{4}{*}{200} \\
\hline & & Rs.5000-Rs.15000 & 51 & $25.5 \%$ & \\
\hline & & $\begin{array}{l}\text { Rs. } 15000- \\
\text { Rs.20000 } \\
\end{array}$ & 12 & $6 \%$ & \\
\hline & & Above Rs.20000 & 11 & $5.5 \%$ & \\
\hline
\end{tabular}


Table 2: Scoring of each item

\begin{tabular}{|l|l|l|l|l|}
\hline S.No & Dimension & Question no. & \multicolumn{2}{|l|}{ Scoring } \\
\cline { 4 - 5 } & & 1 & Yes & No \\
\hline 1. & Computer Literate & 2 & 1 \\
\hline 2. & Aware of the following e-learning resources & 2 to 13 & 2 & 1 \\
\hline 3. & e-learning resources in for curriculum delivery & 14 to 25 & 2 & 1 \\
\hline 4. & $\begin{array}{l}\text { Problems in the utilization of e-learning resources for } \\
\text { curriculum delivery }\end{array}$ & 26 to 31 & 1 & 2 \\
\hline
\end{tabular}

Table 3: Scoring of each item

\begin{tabular}{|l|l|l|l|l|l|}
\hline S.No & Dimension & Question no. & Scoring \\
\cline { 4 - 6 } & & $\begin{array}{l}\text { Accepted } \\
\text { \& Used }\end{array}$ & $\begin{array}{l}\text { Consider } \\
\text { being } \\
\text { use }\end{array}$ & $\begin{array}{l}\text { Not } \\
\text { interested }\end{array}$ \\
\hline 1. & $\begin{array}{l}\text { Awareness \& intentions of some } \\
\text { common E-resources technology } \\
\text { related actions }\end{array}$ & 32 to 51 & 3 & 2 & 1 \\
\hline
\end{tabular}

Table 4: Ranks assigned for the scores

\begin{tabular}{|l|l|}
\hline Awareness of E-resources \\
\hline Scores & Rank \\
\hline 51 to 75 & Low \\
\hline 76 to 100 & moderate \\
\hline 101 to 122 & High \\
\hline
\end{tabular}

\section{Hypothesis 1:}

There will be a significant mean score difference in the awareness of e-resources among B.Ed student teachers based on gender.

Table 5: Frequency and percentage difference in the level of mean score difference in the awareness of e-resources among B.Ed student teachers based on gender.

\begin{tabular}{|c|c|c|c|c|c|c|c|}
\hline \multirow[t]{2}{*}{ Gender } & \multicolumn{2}{|c|}{ Low } & \multicolumn{2}{|c|}{ Moderate } & \multicolumn{2}{|c|}{ High } & \multirow[b]{2}{*}{ Total } \\
\hline & $\mathbf{N}$ & $\%$ & $\mathbf{N}$ & $\%$ & $\mathbf{N}$ & $\%$ & \\
\hline Male & 0 & 0 & 5 & 71.43 & 2 & 28.57 & 7 \\
\hline Female & 0 & 0 & 114 & 59.07 & 79 & 40.93 & 193 \\
\hline
\end{tabular}

Table 5 exhibits the result in the level of mean score difference in the awareness of e-resources among B.Ed student teachers based on gender. According to the table amid the male students, $28.57 \%$ of them have high Level and $71.43 \%$ of them have moderate Level of awareness towards e-resources. Similarly, amid the female students, $40.93 \%$ of them have high Level and 59.07\% of them have moderate Level.

\section{Hypothesis 2:}

There will be a significant mean score difference in the awareness of e-resources among B.Ed student teachers based on location of the college. 
Table 6: Frequency and percentage difference in the level of mean score difference in the awareness of e-resources among B.Ed student teachers based on location of the college.

\begin{tabular}{|c|c|c|c|c|c|c|c|}
\hline \multirow[t]{2}{*}{ Locality } & \multicolumn{2}{|c|}{ Low } & \multicolumn{2}{|c|}{ Moderate } & \multicolumn{2}{|c|}{ High } & \multirow[b]{2}{*}{ Total } \\
\hline & $\mathbf{N}$ & $\%$ & $\mathbf{N}$ & $\%$ & $\mathbf{N}$ & $\%$ & \\
\hline Urban & 0 & 0 & 62 & 78.48 & 17 & 21.52 & 79 \\
\hline Rural & 0 & 0 & 57 & 47.11 & 64 & 52.89 & 121 \\
\hline
\end{tabular}

Table 6 exhibits the result of the difference in the level of mean score difference in the awareness of e-resources among B.Ed student teachers based on location of the college. According to the table amid the urban area students, $21.52 \%$ of them have high Level and $78.48 \%$ of them have moderate Level of awareness towards e-resources. Similarly, amid the rural area students, $52.89 \%$ of them have high Level and $47.11 \%$ of them have moderate Level.

\section{Hypothesis 3:}

There will be a significant difference between awareness of e-resources among B.Ed Student teachers with respect to gender.

Table 7: ' $t$ ' values between awareness of e-resources among B.Ed Student teachers with respect to gender

\begin{tabular}{|l|c|c|c|c|c|c|c|}
\hline Gender & Number & Mean & S.D & df & $\begin{array}{c}\text { t } \\
\text { value }\end{array}$ & p-value & Remarks \\
\cline { 1 - 6 } Male & 7 & 1.37 & 0.32 & 200 & 0.12 & 0.45 & $\begin{array}{c}\text { Not } \\
\text { significant }\end{array}$ \\
\hline Female & 193 & 1.45 & 0.21 & & & &
\end{tabular}

(at 0.05 significant level the table value of ' $t$ ' is 1.98)

Since the calculated value (0.12) is less than the table value of ' $t$ ' $(1.98)$, the null hypothesis is accepted. It is inferred from the above table that there is no significant relationship between awareness of e-resources among B.Ed Student teachers with respect to gender.

\section{Hypothesis 3:}

There will be a significant difference between awareness of e-resources among B.Ed Student teachers with respect to gender.

Table 8: ' $t$ ' values between awareness of e-resources among B.Ed Student teachers with respect

\begin{tabular}{|l|c|c|c|c|c|c|c|}
\hline Gender & Number & Mean & S.D & df & $\begin{array}{c}\text { t } \\
\text { value }\end{array}$ & p-value & Remarks \\
\hline Male & 7 & 1.37 & 0.32 & 200 & 0.12 & 0.45 & $\begin{array}{c}\text { Not } \\
\text { significant }\end{array}$ \\
\hline Female & 193 & 1.45 & 0.21 & & & &
\end{tabular}

(at 0.05 significant level the table value of ' $t$ ' is 1.98)

Since the calculated value $(0.12)$ is less than the table value of ' $t$ ' (1.98), the null hypothesis is accepted. It is inferred from the above table that there is no significant relationship between awareness of e-resources among B.Ed Student teachers with respect to gender. 


\section{Results And Conclusion}

- Majority of the male and female have moderate level of awareness towards e-resources. But comparatively, the female students have high level of awareness towards e-resources than the male students.

- Majority of the urban area students have moderate level and in contrast rural area students have high level of awareness towards e-resources. But comparatively, the rural area students have high level of awareness towards e-resources than the urban area students.

- Majority of the UG and PG qualified students have moderate level of awareness towards e-resources. But comparatively, the PG qualified students have slightly better awareness towards e-resources than the UG qualified students.

- Majority of the nuclear family students have moderate level of awareness towards eresources whereas the joint family have equally distributed to high level and moderate level awareness towards e-resources. But comparatively, the joint family students have slightly better awareness towards e-resources than the nuclear family students.

- There is no significant relationship between awareness of e-resources among B.Ed Student teachers with respect to gender, location of the school, educational qualification, type of family, medium of instruction, nature of college, educational qualification of father, educational qualification of mother, occupation of father, occupation of mother , monthly income of father and monthly income of mother.

\section{References}

[1] Collis, B.,and Jung, I.S.(2003). Uses of ICT in teacher education,. In B. Robinson \& C.Latchem (Eds.), Teacher education through open and distance learning, London: Routledge Falmer, pp.171192.

[2] Nachimuthu, K. (2007) Mobile learning and Distance Education, Journal of Distance Education, University of Jammu, 2007, Vol. XII, No:1, pp. 33-39

[3] Amedu, S. O. (2014). Assessment of the Uses of E-learning Facilities by Home Economics Teachers in Teachers in Delta state, Nigeria. Journal of Education and Practice. Vol. 5 (16) pp207212.

[4] Taylor, R. W. (2002) Pros and cons of online learning - A Faculty perspective, Journal of European Industrial Training, Vol. 26, No.1, pp.24-37.

[5] Vijayakumari, G., et al (2008) Quality issues and standards of E-content, Journal of Educational Technology, I-Manager Pub, Vol. 04, No. 03, Oct-Dec 2007, pp. 8-11

[6] Anene, J. N., et al, (2014). Problems and Prospects of Elearning in Nigerian Universities. International Journal of Technology and Inclusive Education (IJTIE). Vol.3 (2) pp320- 327. 